\title{
4.6 CONTEMPORARY IMPORTANCE OF LEADERSHIP IN THE CONCEPT OF COLLECTIVE ENTREPRENEURSHIP IN AGRICULTURE
}

Summary: Nearly $2 \mathrm{mln}$ individual farmers, including a few thousands of product manufacturers, have the weakest position in the processing and trade chain from a manufacturer's field to a final consumer's table compared to frequently less numerous, though much larger, environment entities in agricultural trade, processing and commerce. Agricultural producers have to change their method of activity on the market to defend their own economic interests. Agricultural producers groups are an example of such activities. The paper presents contemporary importance of collective entrepreneurship in agriculture as well as the extent of organization in the agricultural producers groups in Poland in the space of the last decade. The paper pays also attention to the importance of effective leadership in the process of creation and functioning of such groups. These are the skills that an effective group leader should be characterized with are shown. An analysis of leadership styles was carried out and the most effective of them for collective entrepreneurship were specified.

Keywords: agricultural producers groups, entrepreneurship, leadership, leadership styles

\section{INTRODUCTION}

The contemporary model of organization management assumes that a success is achievable thanks to the use of a proper "philosophy of thinking", which may be defined as the orientation at the market entrepreneurship and as arousing in human resources an attitude of loyal, emotional engagement in the organization development. The main principles of such philosophy may include: market culture understood as the subordination of all actions to clients; clear, understandable goals, mission and strategies of the organization (a clear concept of the enterprise development prepared for changing market conditions); continuous improvement culture (innovativeness), i.e. seeking changes and reacting to them; recognizing people as the most important resources of each organization, capable of continuous development for its benefit (Penc, 1996).

A success of each human activity depends on many simultaneously impacting factors of which some are dependent, whereas others are not. Independent factors create so-called conditions for taking actions and they include inter alia currency exchange rates, taxes, competition, regulations of law, costs for means of production etc. Whereas human-dependant factors worth mentioning include: adopted operational strategies, distribution of obligations, adopted motivational system that is of integrative impact, adopted organizational structure or organizational - legal form, decision related to the choice of a leader and, what follows, adopted leadership style.

The necessity of farmers organizing in business structures results from such basic prerequisites as: 1) economic globalisation and its consequential risks, 2) specificity and characteristic features of agriculture as a sector of national economy, 3) style and philosophy of life and work of farmers. Producer groups constitute a counterweight; a positive reply towards structural transformation taking place in agriculture at the beginning of the $90 \mathrm{~s}$ being the manifestation of the economy adjusting to operate according to new market mechanisms. They support local and national culture and tradition, the natural environment protection, and developing community ties. Irrespective of a farm size a farmer as a business entity is a small unit. Framers organizing themselves into agricultural producer groups enable better 
production planning and its adjustment to client needs, decrease of production costs per a farm by joint purchase of means for production, joint use of equipment, preparation of products for trading and organization of their sale, as well as better access to information. As a result of combining the capital and the above mentioned benefits farmers are likely to be more interested in investments and implementation of innovatory solutions into their farms.

The objective of this paper is to present the process of formation and development of collective entrepreneurship within rural areas as well as to indicate how important effective leadership of such group is in this process. The primary source of information used to fulfil the assumed objectives included the secondary sources of research material, mainly literature of the subject as well as the results of own surveys conducted among 150 farmers organized in 28 agricultural producer groups.

\section{CONTEMPORARY IMPORTANCE OF COLLECTIVE ENTREPRENEURSHIP IN AGRICULTURE}

The term "entrepreneurship" appeared for the first time at the turn of the $18^{\text {th }}$ and $19^{\text {th }}$ century. The beginnings of scientific and research interest in entrepreneurship should be sought in the industrial revolution and the pioneers of nascent capitalism. It was related to the formation of the then new forms of management, administration, and economisation of social life by proper use of the capital, technical, raw material, and human potential. The capital allocation was accompanied by quite a risk. It was related to the chance of faster profit multiplication; however, it equally often caused a decline and bankruptcy. The entrepreneurship was explained in the works of the representatives of economic and social liberal thought. A. Smith, J. B. Say and J. Schumpeter are considered to be its precursors: (Potocki, 2000).

Presently the term entrepreneurship defines as a certain feature of actions aimed at rational and effective use of organization resources. The entrepreneurship defined this way is a multidimensional phenomenon. It may be for example considered in the economic (process) or social dimension.

The entrepreneurship in the economic dimension is understood as the mode of action consisting in taking up new, risky and unconventional tasks and in demonstrating initiative in their search and implementation in life. Thus it is the development-oriented action, is of innovatory character. The entrepreneurship in the economic dimension consists in:

- creating more effective organizational forms,

- introducing new factors of production,

- acquiring new sales and supply markets,

- launching new products (Kortan, 1997).

Thus one may risk making a statement that entrepreneurship is the actions of organized nature, oriented at the skills of generating and using innovatory ideas for achieving measurable benefits realized in risk conditions.

In a bit wider social meaning entrepreneurship is a feature, in fact a set of psychological features making somebody a good entrepreneur, such as dynamism and activeness in terms of noticing needs and improving ideas, the ability to take opportunities, the adaptation skill in changing conditions and readiness to take risks. Entrepreneurship is an individual feature of human personality, characterised with intelligence, innovativeness, the ability to perceive conditions and relations occurring between economic phenomena and the ability to organize trading, industrial and service activity ensuring the advantage of incomes over income costs. Entrepreneurship is the innovation consisting in searching for distinctness compared to what others do, finding more effective methods of operation to be used on the market and ensuring higher usability of products and services as well as increased effectiveness of management. 
By its nature this activity is competitive to the operation of other enterprises (Fabiańska, 1986).

Depending on the method of task realization and the scope of human cooperation, entrepreneurship can be divided into individual and collective entrepreneurship. In case of individual entrepreneurship we speak of actions taken by an individual for the purpose of establishing and managing own company. Whereas collective entrepreneurship stands for organized, conscious and voluntary cooperation of people oriented at the achievement of a common goal, inter alia thanks to the bigger allocation of owned means, decrease of production costs (economies of scale and range), increase of the impact on the market (increase in the market share). Collective entrepreneurship gives the opportunity, in particular to smaller business entities, to develop their hitherto operations or to implement new ones.

One of the forms of collective entrepreneurship is the network organization created by a few independent organizations connected with one another by means of corporate bonds of various character. For example the following forms of integration may be distinguished: vertical one (network of organizations related to large companies), horizontal one (network of organizations manufacturing/producing similar goods most frequently within a given territory), vertical disintegration (network of small organization created by a large enterprise) or a network created via incubation.

Majority of agricultural producers groups are examples of horizontal integration. They are created by owners of farms specializing in the same production field, having comparable production capacities (farm area, marketability, financial and tangible resources) and functioning within the same territory. The intentional selection of farms is one of the conditions for such activities to be taken. At this point a local community leader plays an important role as he when noticing new possibilities takes pains to organize and manage a group of people.

One of the first definitions explaining the essence of functioning of such agricultural producer groups was formulated by J. Małysz (Małysz, 1996). According to him a producer group (producer team) is created from the bottom up and voluntarily for the purpose of collective sales of products. Joint marketing enables a group of farmers to increase their bargaining power and consequently to achieve higher prices for sold products and to incur

lower prices for purchasing means for production. Farmers acting together enjoy an easier access to market and scientific information, to external financing sources as well as better investment possibilities. The restriction of farmers' activity mainly to common market does not alter the property relations. Such change may occur only when as a result of income earning a possibility of investing into plants for pre-processing, storage and transport appears. Consequential joint asset is managed collectively by farmers. However, it is totally separated from their individual properties. Each farm still is an independent business entity. A collective property, the owners of which are all members of a producer team, increases their bargaining power and allows achieving better sales conditions on the market. Such producer team is an example of the horizontal integrity whose substance is the connection of business entities belonging to the same production zone or distribution. However, in such case only the following activities are integrated horizontally: e.g. supply of raw materials, sales of agricultural products etc. Still though we deal with independent business entities.

\section{ORGANIZATIONAL - LEGAL FORMS OF THE AGRICULTURAL PRODUCERS GROUPS}

The group of agricultural producers is not an organizational-legal form. It is established in an entirely voluntary and spontaneous way. It bases its initial activity mainly on informal ties within the community of interest of individuals. However, wanting to pursue their business 
activity for a longer period of time, and what is more important, to develop it, going into a higher step of organization and giving the group a defined business entity becomes a must. The choice of a legal form of a business entity that would suit best a particular agricultural producers group is a very important and difficult decision. A legal form should not restrict a business activity and it should enable the group to fulfil its goals in the best possible way.

While choosing a legal form for a producer group a few issues that will facilitate decisionmaking need to be considered.

Above all a clearly defined target as well as the range and scope of a planned venture are of significance. Farmers may organize themselves to achieve only economic targets, but also social or lobbyist ones. This is the goal that mobilizes a group of farmers is the element playing a decisive role in the choice of a legal form. If a producer group sets its primary sight on social, educational, lobbyist activity (e.g. to improve their skills and tools) it is enough to choose such form that will enable such goal achievement. Whereas, if the main intention of producers is to pursue a business activity, then in case of an association, such activity is not permitted anymore. These types of activity can be carried out in the form of a commercial law company, a civil partnership, a cooperative, or an affiliation.

Figure 1: Percent of agricultural producer groups according to legal forms

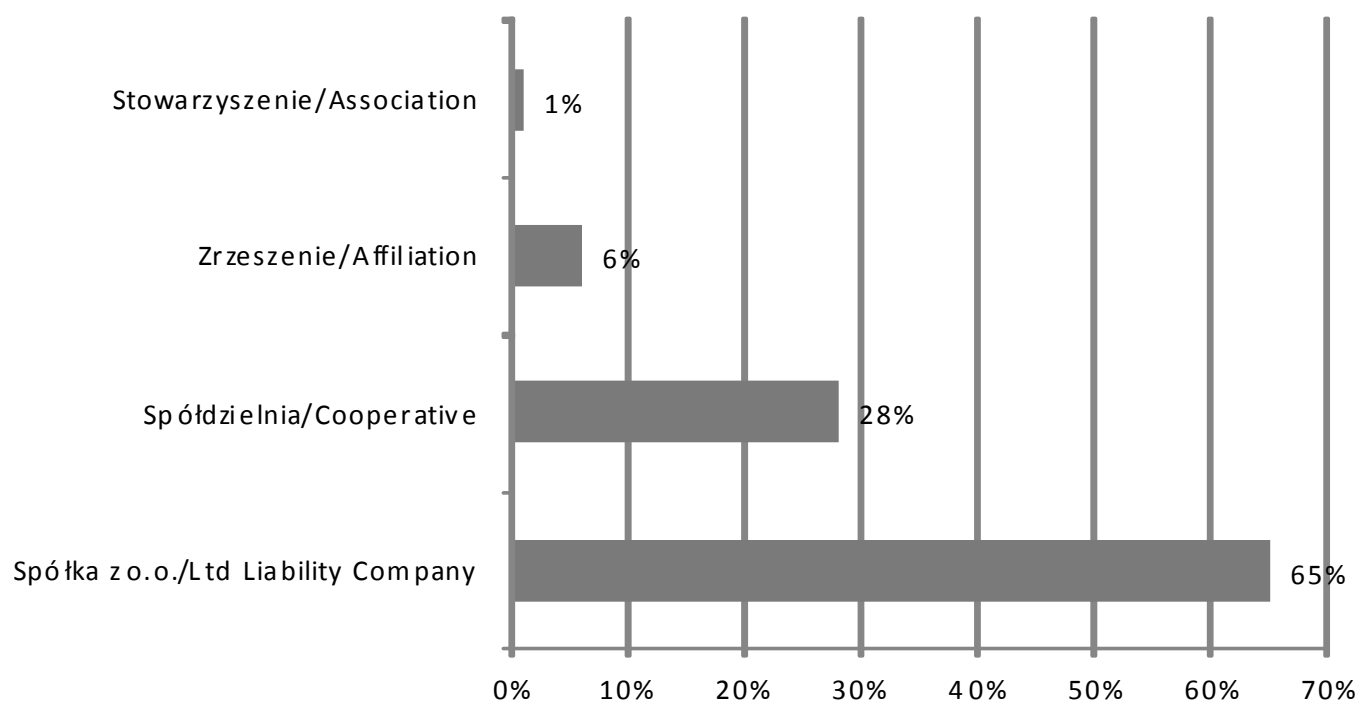

Source: Promotion of establishing agricultural producer groups. Ministerstwo Rolnictwa i Rozwoju Wsi [Ministry of Agriculture and Rural Development], Warsaw 2011, p. 4.

Out of the legal forms framers tend to choose a limited liability company and a cooperative most frequently ( $65 \%$ and $28 \%$ correspondingly). The two other forms to be chosen from enjoy smaller interest, i.e. an affiliation $-6 \%$ and an association $-1 \%$. A form of a joint stock company is practically not used to establish producer groups inter alia because of its complex and complicated character of operation.

\section{ORGANIZATION STATE OF THE AGRICULTURAL PRODUCERS GROUPS}

The problem of agrarian fragmentation in the Polish country still is one of key problems of Polish farming, which was expressed in the Rural Development Program for the years 20072013 where the issue of agrarian fragmentation was classified as an indirect or direct reason for low capacity of agricultural production, low incomes of farmers, low crops, low quality production or also setting fields aside. It is estimated that out of over $1.5 \mathrm{mln}$ farms in Poland only ca. 500 thousand are the farmers producing for the market. In the group of market farms 
there are both farms specialized in the production of a particular product or groups of products as well as multidirectional, non-specialized ones. With a view to both of them, the act on agricultural producers groups and their associations was adopted in 2000 aimed at supporting the economic process of farmers organizing themselves and strengthening the market position of Polish agricultural producers (Journal of Laws of the year 2000 no. 88, item 983 as amended). It serves as the basis for agricultural producers to organize themselves in Poland and in turn to organize unions. Under this act, natural persons running a farm as defined in the rural tax regulations and natural persons carrying out an agricultural activity within the scope of special branches of agricultural production may organize themselves into agricultural producers groups so as to adjust the agricultural production to market conditions, to improve farming effectiveness, to plan the production paying particular attention to its quantity, quality and the supply concentration as well as to arrange sale of agricultural products and to protect the natural environment. Joint management of such group's activity whose target is to maximize the profit of its individual members may be called the collective entrepreneurship.

As of $30^{\text {th }}$ November 2011 as many as 784 agricultural producers groups uniting ca. 25,000 members were registered in the registers kept by marshals of voivodeships from all over Poland. The biggest number of groups was established after 2004 since when a successive increase of the number of newly established groups has been reported. According to statistical data the agricultural producers groups developed most dynamically in 2008 when 158 groups were founded 135 groups in 2009 and 177 groups in 2011.

Figure 2: Agricultural producers groups entered into the registers kept by voivodes /marshals in the years 2001-11.2011.

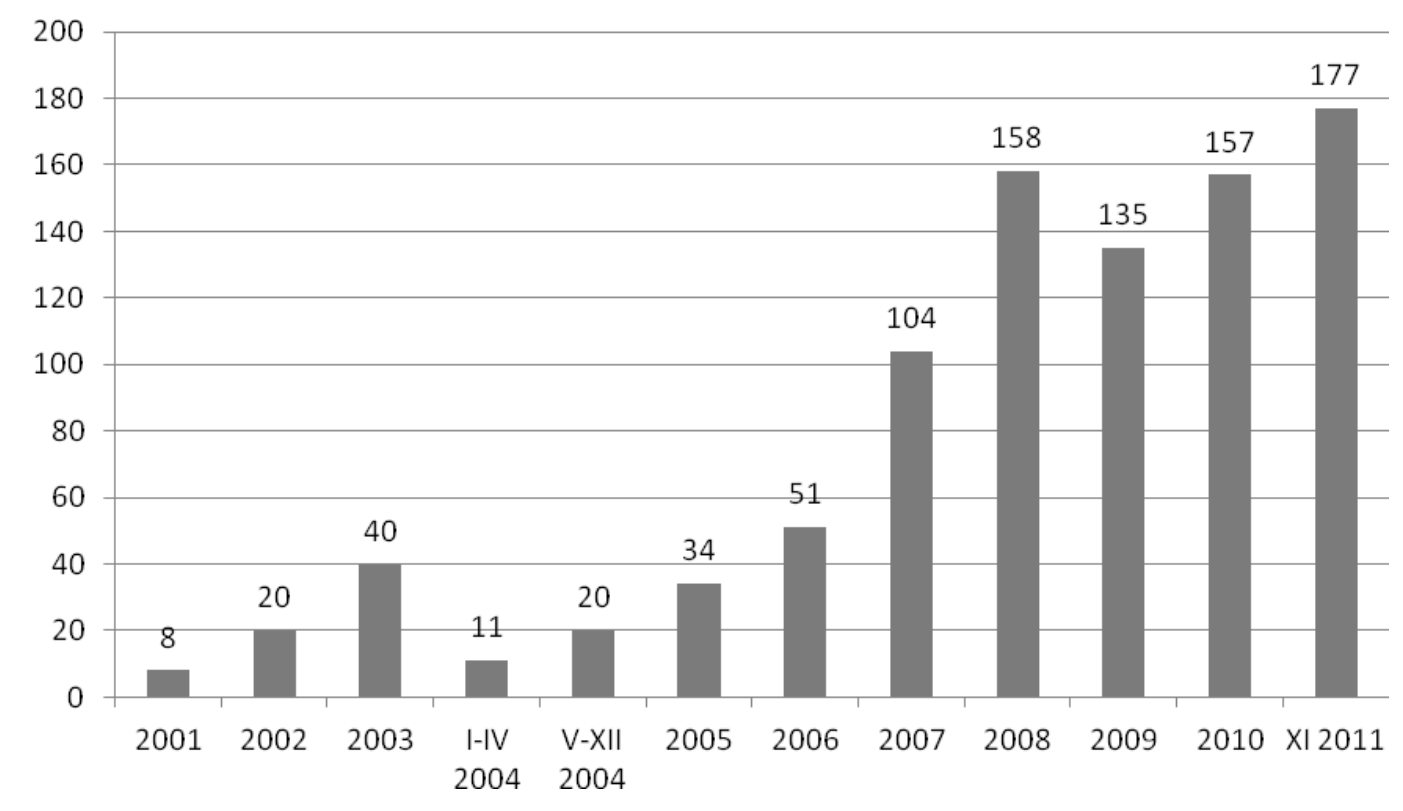

Source: Promotion of establishing agricultural producer groups. Ministerstwo Rolnictwa i Rozwoju Wsi [Ministry of Agriculture and Rural Development], Warsaw 2011, p. 13.

Most producer groups is established in the regions, where there is the concentration of a given product, where there is a significant percent of dynamic farms which modernize actively and keep on investing in the productive capacity. They are most frequently bigger farms that are better organized and whose owners are young and more creative. The process of farmers organizing into producer groups takes place quicker in the areas of West and North-West Poland, where bigger farms, including specialist ones, constitute the majority.

In terms of the number of groups, the following voivodeships take the lead: Wielkopolska Voivodeship (173 groups), Lower Silesia Voivodeship (99), Kuyavian-Pomeranian 
Voivodeship (98) and Opole Voivodeship (79). The weakest organization rate characterizes the voivodeships of South-East Poland where small and medium farms constitute the majority (Świętokrzyskie Voivodeship (11) and Małopolska Voivodeship (11)). The formation process of the agricultural producers groups in Poland is not yet advanced (only $2 \%$ of agricultural producers, who are mainly larger-scale producers, are members of the agricultural producers groups). From the point of view of market competitiveness and lobbyist power it is not the number of the groups themselves that is of importance, but the number of members such groups are composed of. The process of farmers organizing themselves into groups can be considered successful in case of Wielkopolska Voivodeship where nearly 3,000 producers are members of the groups. While in case of voivodeships, where in groups there are 100, 200 or 500 producers we can speak of the process failure and that refers to the majority of voivodeships of Poland.

Despite a large progress, particularly in recent years, still the economic organization rate of agricultural producers is one of the weakest aspects of Polish farming. The state of agricultural producers organizing themselves into groups varies in individual branches. So far 22 groups have been established per 35 products and product groups for which agricultural producers groups may be created. The vast majority brings together producers of cereal grains, oilseeds, pigs and poultry. Despite numerous efforts made by the state authority to support the formation process of agricultural producers groups, the organization state of Polish farmers is still very low.

The developed activity of various agricultural institutions and organizations, mainly agricultural advisory centres, apart from social and economic reasons, is yet another important motif for farmers to organize themselves into groups. These centres belong to the institutions that thanks to advisors employed there support educationally all positive changes in farming. Advisory institutions try to provide full-scope consultancy related to the process of formation and operation of the agricultural producers groups, the evidence of which is a large-scale informative activity of advisory environments (concerning targets of such group activity, possibilities and methods of its operation, presenting a detailed analysis of the agricultural market, present conditions and perspectives of the operation on the market).

Methods of agricultural consultancy are changed or modified. To be able to provide farmers forming agricultural producers groups and commencing joint activity with assistance new elements within consultancy have appeared and they are as follows: consultancy within agricultural law, economic consultancy, marketing consultancy and technological consultancy oriented mainly at the improvement of product quality and gradual orientation of group members at a uniform production process, which sometimes requires the introduction of some changes into the production profile, the increase of the specialization extent and the size of particular production.

\section{ROLE OF LEADERSHIP IN THE FORMATION OF THE AGRICULTURAL PRODUCERS GROUPS}

The essence of agricultural producers groups' functioning is based on mutual assistance and cooperation. It is all about the cooperation factor that is of conscious and voluntary nature and based mainly on the means of the ones concerned. The essence of collective entrepreneurship expressed in the form of agricultural producers groups can be looked at from different points of view: economic, social, political, and ethical one. The agricultural producers groups should not be identified with a pure economic category.

A lot of both endogenic and exogenic conditionings are bound to influence the operation of agricultural producers groups. One of the most significant conditionings that are identical for each group are the features characterizing a social group understood as a certain number of 
people distinguished on the grounds of formal and informal membership criteria, feeling the community spirit with other group members or such individual between which interactions of relatively fixed model take place. These features include the group target, group norms, group structure, group leadership and group cohesiveness.

The dynamics of formation and functioning of the agricultural producers groups, in fact, does not differ from the dynamics of social groups described by social psychology researchers. For example, Aronson in his work The Social Animal when explaining functioning of individuals in a society emphasizes that man is by his nature a social creature and only functioning in set social structures can feel comfortable and safe. Starting with such assumption, we may adopt the thesis that the provisions of proper conditions for functioning of agricultural producers groups will allow to popularise this form of cooperation. One of the conditions for success is the effective leadership consisting in the ability to create and manage a group. A characteristic feature of human groups is its hierarchicalness, i.e. having a leader who but for managing and realizing tasks may also prevent inner conflicts from taking place. His position is stronger; it is to him that other member of the group most often subordinate voluntarily. Such situation lasts until the breakdown of interest between the leader and the group takes place. Then we may deal with a breakdown of the group or a change of the leader (Krawulski, 2000). At the very beginnings of their functioning the agricultural producers' groups consultancy teams played an important role within this scope. By propagating, the idea of collective entrepreneurship in farming advisors established cooperation with leaders of social communities and encouraged them together to unite. As the surveys conducted among members of the agricultural producers groups show it was the advisors who had the biggest influence on decisions related to establishing a group. The support in terms of consultancy at the decision-making and organizational stage (choice of the organizational-legal status, preparing statutes, preparing documentation necessary for group registration etc.) resulted at the beginning of the $90 \mathrm{~s}$ in the appearance of many initiatives of formation of such business entities controlled by farmers. Unfortunately, a large number of then established agricultural producers groups have never even commenced their business activity. Leaving aside the fact that the group formation process is difficult the slow pace of development of this type of organization was the consequence on numerous barriers arising from external conditionings during that period (no legal regulations related to producer groups, no financial and organizational support, unfavourable tax system etc.) as well as internal barriers related to a farmer (the biggest barrier was the mentality of farmers themselves and difficulty to find a leader with a vision who would be able to lead such group of agricultural producers). It is an often case that members of the newly established groups can be divided into those who participated actively in the group formation and still strive for its development and those who join the group for preventative reasons (so as not to be worse than others) and do not participate actively in group activities (Parzonko, 2006). Such situation is a contradiction to the idea of healthy cooperation. Despite that, there are many examples of receiving financial support by groups which has a motivating effect on others, also the awareness among farmers increases and possible benefits of engaging into joint activities on the market are visible.

Hitherto experience within the development of the agricultural producers groups proves how important is the role of effective leadership in this process. A good leader gives the group a chance for effective activity oriented at the achievement of group goals and its further development. A leader is an individual who is perceived by other group members as the one entitled to manage the group. He may be chosen or appointed for this position. He may also become a leader as a result of interactions or voting taking place in the group (Fujishin, 1997).

Leadership is the process of influencing others for the purpose of achieving set goals in set situations without using techniques excessively based on extortion (Kuc, 2004). Leadership consists in the use of influence without applying extortion measures with the intention to 
shape a group or an organization, to motivate behaviours oriented at such goal achievement (Griffin, 1998). For this reason, the leader is characterized as the person influencing the behaviour of others without the necessity of using force. In the process of formation and operation of agricultural producers groups, the person of a leader plays a key role, because, as Krzyżanowska notices, even formal groups may find effective functioning difficult if they do not have an active, operative leader engaged in the group affairs (Krzyżanowska, 2000).

Depending on a group, its goal and existence stage, the manager may fulfil a number of varied functions such as for example:

- the coordinator of the group activity,

- the person setting targets and policy of the group,

- the person planning methods and means for the purpose of the achievement of the group target,

- the representative of the group externally,

- the controller of intergroup relations,

- the role model of behaviour for other group members etc.

The ability of effective and efficient group leadership is conditioned by both inborn predispositions as well as life experience of an individual. Authors dealing with the issue of leadership present different views as regards the attribution of importance to genetic and learned factors. Some maintain that inborn features are most important, that they condition certain reaction methods and styles of their contacts with a group. Whereas others emphasize that leadership skills are acquired while enlarging one's base of experience and field of selfawareness (Woyach, 1995). The knowledge about human reactions to social influences such as submissiveness, identification and internalisation allows to remember and systematize experience so that it could influence positively a leader's further activity. Submissiveness is the behaviour of a person who is motivated by a desire to be awarded or to avoid punishment. Such behaviour usually lasts as long as the promise of award or threat of punishment is used, thus it is short-term. Identification is the reaction elicited by an individual's desire to be similar to a person such impact comes from. An individual in fact starts to believe in opinions and values that they assume, though not always strongly. If somebody assumes a certain view in the course of identification and then learns counterarguments presented by a trustworthy and knowledgeable person, they are likely to change their opinion. Internalisation of any value is the most permanent reaction to social influences. If we find a person exerting influence trustworthy and having good judgement of reality, we accept a conviction expressed by such person and include it into our system of values. The motif of the aspiration for rightness that we deal with in case of internalisation is a great and self-support force. As for submissiveness an important component is the power that a person exerting influence has in terms of awarding for submissiveness and punishing for the lack of submissiveness; as for identification the decisive component is the attractiveness of a person we identify with, whereas as for internalisation it is the credibility of a person delivering information. These three components jointly compose the competence of a contemporary organization manager. However, the agricultural producers groups cannot be labelled like this due to the dissimilarities arising from their character of activity, different structure of mutual ties and internal impacts and, above all, the culture shaped by many generations of farmers. Thus, while divagating upon efficient leadership in the agricultural producers groups the greatest importance will be placed on credibility, then attractiveness of a leader, whereas power (arising in addition from the possibility of awarding and punishing) may not help at all, but, in fact, it may hinder such group management. Group members perceive the person of a leader as attractive in terms of personality features, as valuable and thus estimable and likeable. Simultaneously, a leader is also a person who is likely to have information necessary for efficient functioning of the group, that are the grounds of any action, a person cooperating 
with institutions supporting the functioning of producer groups and organizations with which a group will cooperate or has already started the cooperation.

To create a primary profile of competences of the agricultural producers group-leader empiric survey was conducted among 150 farmers organized in 28 groups were conducted. Majority of group members surveyed was of the opinion that the most important features of the leader are:

- ability to cooperate with others to achieve a common goal ( $86 \%$ replies),

- ability to win the favour of followers (63\% replies),

- ability to exert influence on a given rural community (54\% replies).

Figure 3: Profile of the leader in the opinion of agricultural producers' group member (\%)

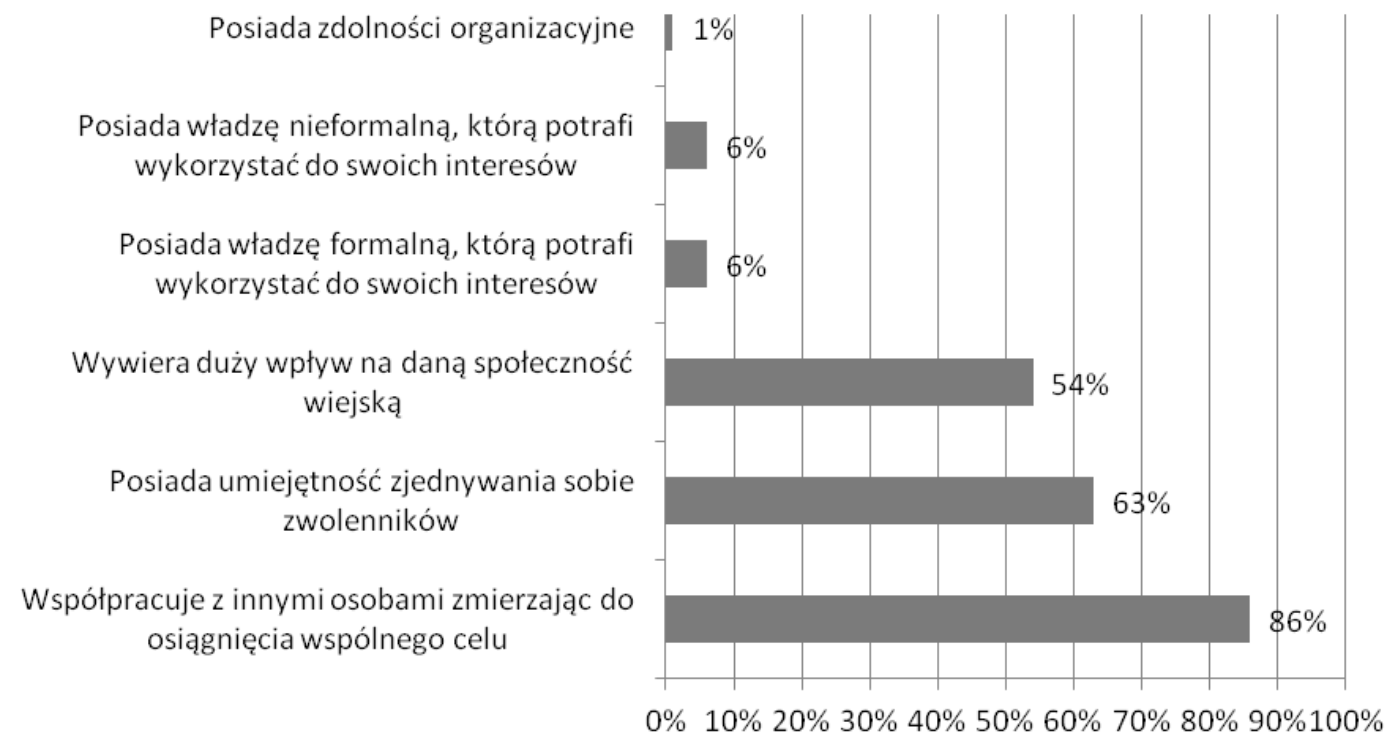

Legend (translated from the top):

- Having organizational skills

- Having informal power that he is able to use for his interest

- Having formal power that he is able to use for his interest

- Exerting a large influence on a given rural community

- Having the ability to win the favour of followers

- Cooperating with others to achieve their common goal

Source: own survey

From the analysis of farmers' opinions concerning group leader it may be concluded that a person characterized with a democratic style of management will be the most effective leader. It is a person cooperating with other group members, sounding them out while formulating tasks, consulting their distribution and purposefulness. Such leader prefers collective work, tries to eliminate possible barriers hampering group communication. He tries to create a good atmosphere in his subordinate group and his contacts with subordinates are based on partnership. A small percent of respondents showed that their group leaders used the fact of having formal/or informal/ power to pursue their own interest ( $6 \%$ replies each). The attitude of respondents to the leader's organizational skills is interesting as they were appreciated by only $1 \%$ of respondents. Failure to notice the necessity of having organizational skills arises from the fact that the most important activities concerning the organization and the entire process of group establishment were taken by rural advisors in most cases

The effectiveness of leadership impacts (in other words leadership styles) is conditioned not only by skills and personality predispositions of a leader, but also by factors that he has no influence on or that he exerts insignificant influence on. These factors may include the 
character of tasks a group faces, time restrictions concerning the performance of these tasks as well as expectation of other group members. Applying the path goal theory developed by R. House (the "path to goal" concept" arises from the conviction that efficient leader shows his path to help his subordinates to overcome the distance between the place they are in presently and the goal) four styles of leadership behaviours can be distinguished:

- a directive leader i.e. the one who informs subordinates what he expects from them, who programs works and gives detailed guidelines as regards the way tasks are to be performed in;

- a supportive leader is a friendly person, demonstrating concern for the fulfilment of subordinates' needs;

- a participative leader is such type of a superior who sounds his subordinates out and makes use of their help in a decision-making process;

- an achievement-oriented leader sets subordinates difficult goals and expects from them the highest effectiveness (Robbins, 1998).

In case of the issue of leadership in agricultural producers groups, not every style mentioned above will be effective. The most effective leaders do not limit themselves to just one style. Every week they make use freely and equally of all leadership styles which are adjusted to the particular situations. Since a producer group leader is selected from a group of people who know one another well, who are often on friendly terms and function in the same local environment it is a highly probably assumption that traits of supportive and participative styles can be recognizable in his actions.

Primarily a contemporary leader inspires and animates necessary actions, relies on competences, commitment, independence and responsibility of other group members so that the group could implement positive changes and achieve set goals. A good leader is the person who is able to carry out a pertinent analysis of the situation and to suggest how to achieve goals, finally to distribute duties in such a way that everyone would deserve credit for the goal achievement. A leader ensures the best opportunities for effective initiation and management of a group cooperation at the implementation of various projects and social and economic activities. Well-organized activities of agricultural producers groups' members give a chance to achieve the so-called synergism effect, thus to achieve as a result of cooperation much better outcome than the sum of outcomes that farmers may achieve individually. The method of actions chosen by a leader and the difficulty degree in terms of a given group management depend largely on features of other group members. If its members have high qualifications and a vast range of experience and knowledge it may be assumed that, they will cope with a task with a small involvement of a leader. The higher the qualifications, experience and knowledge of group members the easier it is to manage a group.

The most desirable form of leadership in a democratically managed group is a so-called shared leadership in which each group member feels responsible for the group and effects of its activities. There are two dissimilar approaches explaining the leader-selection issue. The first approach points at personality features of potential leaders, the other one - on the situation, which requires particular actions that may be taken by only a given person and not by another. In case of the way agricultural producers groups function an intermediate concept seems best, i.e. the concept that conditions a leader-selection on both a situation as well as his certain features. For example if the situation a group requires activeness, in such case a person having such feature will become a leader, whereas, if the situation requires the ability to solve particular problems, a person who is able to solve such problems may become a leader. In the moment of a particular task realization the persons that within a given scope is most competent becomes a group leader. The more the group members share leadership functions, the bigger the motivation to act jointly is and the more proper the decisions jointly made are (Boguta, 2008). 
Each group member should be aware of his rights as well as of his obligations towards the group, as a success of the group and thus of each of its members depends on proper fulfilment of obligations by members themselves and by the board. For this reason it is important to define clearly the role of members, board and employees in a group.

Taking into consideration recognized preferences, advantages and limitations of group members a leader can manage the team work skilfully to use the energy of people maximally, to extract their entire potential, to develop group activities and to achieve successes.

Roles those are advantageous to cooperation and development of a group:

- motivator - a good spirit of a group, activates to action, gives credit,

- listener - is able to listen carefully,

- rock - gives support to persons who need it, is warm and cordial, enjoys trust and liking,

- harmoniser - encourages to cooperation, strives for compromises, tries to solve problems and to prevent disputes,

- tension reliever - jokes in difficult situations, like laughing, a guard of principles watches the principles of cooperation and communication,

- fair - watches even distribution of obligations (Boguta, 2008).

The key role within the framework of the organization of group work and protection of its functioning in the agricultural producers group is played by the board. It is best if real group leaders are selected for the board. The board manages current group activity, represents it externally as well as takes all most important decisions that are not restricted for other bodies. However, particularly in small groups each group member feeling responsible for the group and effects of its actions should be ready to act jointly for the benefit of the group.

\section{CONCLUSIONS}

The organization state of Polish farmers put them in a difficult income-competitive position. It refers especially to farmers with medium and small production capacity. In their case, the process of organizing themselves in groups has not brought expected results. Thus initiating for these farmers new, decisive activities aimed at their massive organization into groups by creating proper legal terms, by intensified informational - promotional and educational actions as well as by increasing and shifting financial support to the environments that do need such support is worth considering.

One of the factors that has positive impact on collective entrepreneurship in farming is effective leadership. A good leader is the key to a producer group's success, though the dynamics of a producer group's functioning shows that depending on the group development stage different types of leaders are desirable. Thus, a so-called shared leadership may turn out to be most effective.

Within the space of last several years, the process of growing awareness of benefits that collective entrepreneurship may bring could be observed in rural population. A successive increase in the number of agricultural producers groups shows that this form of cooperation has inscribed for good into the organizational structures of entities functioning in farming.

\section{REFERENCES}

1. Aronson E.(2004): Człowiek istota społeczna, Wydawnictwo Naukowe PWN, Warszawa, s. 41-46.

2. Boguta W. (2008): Organizacja i funkcjonowanie grup producentów rolnych. Krajowa Rada Spółdzielcza, Warszawa, s. 70, 74, 75. 
3. Fabiańska K. (1986): Planowanie rozwoju przedsiębiorstwa, PWE, Warszawa.

4. Fujishin R. (1997): Discovering the leader within: Running small groups effectively. CA: Acada Books, San Francisco, s. 112.

5. Griffin R.W. (1998): Podstawy zarządzania organizacjami. Wydawnictwo Naukowe PWN, Warszawa, s. 491.

6. Kortan J. (1997): Podstawy ekonomiki i zarządzania przedsiębiorstwem, pod. red. J. Kortana, Wydawnictwo C. H. Beck, Warszawa, s.77,78.

7. Krawulski J. (2000): Public Relations. Wydawnictwo AR w Poznaniu, Poznań, s. 28.

8. Krzyżanowska K. (2000): Psychologiczne i społeczne umiejętności lidera w procesie komunikowania się z grupą. [w:] O humanistyczny wymiar przedsiębiorczości wiejskiej, Red. naukowa Z.J. Przychodzeń, Wydawnictwo SGGW, Warszawa, s. 67.

9. Kuc B. R. (2004): Od zarządzania do przywództwa, Wydawnictwo Menedżerskie PTM, Warszawa, s. 375.

10. Małysz J. (1996): Procesy integracyjne w agrobiznesie. CDiEwR, Poznań, s. 13-14.

11. Parzonko A. (2006): Rola doradztwa w rozwoju rolniczych grup producenckich, Wydawnictwo SGGW. Warszawa, s. 123.

12. Penc J. (1995): Decyzje w zarządzaniu, Wydawnictwo Profesjonalnej Szkoły Biznesu, Kraków, s. 61.

13. Potocki A. (2000): Współczesne tendencje w zarządzaniu - teoria i praktyka, Wyższa Szkoła Przedsiębiorczości i Marketingu w Chrzanowie, Chrzanów, s.19, 20.

14. Robbins S. P. (1998): Zachowania w organizacji, PWE, Warszawa, s.252.

15. Woyach R. B. (1995): Jak zostać przywódcą, Wydawnictwo CDN, Warszawa, s.12. 